$\sqrt{3}$

J. Bio-Sci. 29(1): 135-142, 2021 (June)

ISSN 1023-8654

http://www.banglajol.info/index.php/JBS/index

DOI: https://doi.org/10.3329/jbs.v29i0.54829

\title{
MEIOTIC BEHAVIOUR IN TEN SPECIES OF PTERIDOPHYTES FROM BANGLADESH
}

\author{
MA Mannan ${ }^{1,3}$ and G Kabir ${ }^{*}$ \\ 1Institute of Biological Sciences, University of Rajshahi, Rajshahi-6205, Bangladesh \\ 2Department of Botany, University of Rajshahi, Rajshahi-6205, Bangladesh \\ 3/nformation and Communication Technology Division, ICT Tower, Agargaon, Dhaka-1207, Bangladesh
}

\begin{abstract}
Meiotic behavior of ten pteridophyte species from Bangladesh was analyzed in the present investigation. In SMCs of Adiantum capillus-veneris, thirty distinct bivalents were enumerated. In A. caudatum 16 SMCs resulting 64 spores were observed in sporangium which appeared to be diploid sexual. $A$. lunulatum was found to be triploid apogamous and as diploid sexual forms, thus this species of Adiantum exhibited wide range of morphological variations. Pteris biaurita, $P$. graffithi and $P$. vittata were recorded to be $n=29$ as diploid. In thelypterids, all the four species were observed to be diploid sexual except $C$. dentata when it was tetraploid $(n=36,4 x=144)$. In $C$. arida, meiosis was almost regular with $2 n=72$ chromosomes. $C$. cylindrothrix and Ampelopteris prolifera were also found to be diploid sexual, with $2 n=72$ chromosomes.
\end{abstract}

Key words: Meiosis, Pteridophytes, Spore mother cells

\section{Introduction}

Basic chromosome number along with other cytological information could be considered as important feature for diagnostic descriptions of new plant families or sub-families and may provide clues to the affinities existing between families and their classification into higher categories (Walker 1973). Detection of regular or irregular pairing at meiotic cell division is a powerful tool for detecting the fate of a hybrid plant authentically where other evidence is inconclusive or misleading. Pteridophytes are not exceptions of these. Role of cytology in fern taxonomy has been discussed by many authors (Abraham 1958, Panigrahi 1962, Bir 1970). One important example can be referred here; Copeland (1947) placed Adiantum under Pteridaceae family. The basic number of Adiantum was determined as $n=30$ whereas $n=29$ was enumerated in Pteris. Due to possessing different basic chromosome number, Adiantum was segregated from Pteridaceae and placed in Adiantaceae.

Cytogenetical work helped in the determination of the origin and taxonomic status of several species of Dryopteris, Polysticum, Asplenium, Polypodium, Adiantum, Cyclosorus, etc. The application of cytomorphological knowledge for studying interrelationship at family or group level has been well demonstrated in Thelypteridaceae (Loyal 1963), and in Polypodiaceae (Bir 1973, Bir and Trikha 1979). In case of cytological study no report is available in Bangladeshi fern except Kabir and Mannan (2001) and Azad et al. (2012). So it is evident that a wide gap exists in respect of fern research in Bangladesh. It was observed that three families i.e. Adiantaceac. Ptreidaceae and Thelypterdaceac are predominating in Bangladesh. Under these three families only ten species could be procured abundantly from Bangladesh. Besides the ten species, a few doubtful members were observed which could not be included due to scarcity of the samples. From the

*Author for correspondence: gkabir_3000@yahoo.com 
previous reports it was noticed that these families are also occupying the top position in respect of species number and distribution in Bangladesh. This is one of the reasons to consider these ten species under these three families for meiotic study.

\section{Material and Methods}

Ten species of pteridophytes were used as experimented material is this study. A brief description of all these plants is presented in Table 1.

Table 1. Habitat, distribution and place of collection of ten species of pteridophytes in Bangladesh

\begin{tabular}{|c|c|c|c|}
\hline Specimen & Habitat & Distribution & Place of collection \\
\hline $\begin{array}{l}\text { Adiantum capillus- } \\
\text { veneris } \mathrm{L} \text {. }\end{array}$ & $\begin{array}{l}\text { Dilapidated wall, wet } \\
\text { creeks, sunshades, } \\
\text { terrestrial in few places }\end{array}$ & Throughout the zone & $\begin{array}{l}\text { Panchagarh, Madaripur, } \\
\text { Rajshahi, Jhenaidah, and } \\
\text { Khulna }\end{array}$ \\
\hline A. caudatum $\mathrm{L}$. & $\begin{array}{l}\text { Mainly dilapidated brick } \\
\text { wall }\end{array}$ & $\begin{array}{l}\text { Rajshahi, Pabna, Jessore, } \\
\text { Jhenaidah, Kushtia, } \\
\text { Chuadanga }\end{array}$ & $\begin{array}{l}\text { Rajshahi, Jhenaidah and } \\
\text { Jessore }\end{array}$ \\
\hline A. lunulatum Burm. & $\begin{array}{l}\text { Old wall, sunshade of } \\
\text { buildings, few places as } \\
\text { terrestrial }\end{array}$ & Throughout the zone & $\begin{array}{l}\text { Dinajpur, Bogra, Jessore, } \\
\text { Rajshahi, Jhenaidah and } \\
\text { Rangpur }\end{array}$ \\
\hline Pteris biaurita L. & $\begin{array}{l}\text { Terrestrial, shade and } \\
\text { sunny places }\end{array}$ & $\begin{array}{l}\text { Panchagarh, } \\
\text { PabnaDinajpur, } \\
\text { Thakurgaon, Rangpur, } \\
\text { Bogra }\end{array}$ & $\begin{array}{l}\text { Dinajpur, Panchagarh, } \\
\text { Rangpur and Nilphamari }\end{array}$ \\
\hline P. griffithii Hook. & $\begin{array}{l}\text { Terrestrial, wet and shady } \\
\text { dilapidated brick wall }\end{array}$ & Rajshahi, Nilphamari & Rajshahi \\
\hline P. vittata L. & Brick wall, terrestrial & $\begin{array}{l}\text { Fairly common throughout } \\
\text { the zone }\end{array}$ & $\begin{array}{l}\text { Jhenaidah, Rajshahi, } \\
\text { Faridpur and Magura }\end{array}$ \\
\hline $\begin{array}{l}\text { Ampelopteris prolifera } \\
\text { (Retz.) Reed. }\end{array}$ & Marshy place, terrestrial & $\begin{array}{l}\text { Most common throughout } \\
\text { the zone }\end{array}$ & Natore and Rajshahi \\
\hline $\begin{array}{l}\text { Christella arida (D. Don) } \\
\text { Holtt. }\end{array}$ & Terrestrial & All over the zone & $\begin{array}{l}\text { Panchagarh, Jhenaidah } \\
\text { and Rajshahi }\end{array}$ \\
\hline $\begin{array}{l}\text { C. cylindrothrix } \\
\text { (Rosenst.) Holtt. }\end{array}$ & Terrestrial, moist places & Throughout the zone & $\begin{array}{l}\text { Madaripur, Satkhira and } \\
\text { Naogaon }\end{array}$ \\
\hline $\begin{array}{l}\text { C. dentata (Forssk.) } \\
\text { Brownsey \& Jermy. }\end{array}$ & $\begin{array}{l}\text { Terrestrial, occasionally } \\
\text { on dilapidated wall. }\end{array}$ & $\begin{array}{l}\text { Most common throughout } \\
\text { the zone }\end{array}$ & $\begin{array}{l}\text { Jhenaidah, Rajshahi, } \\
\text { Dinajpur and Barisal }\end{array}$ \\
\hline
\end{tabular}

To study the meiotic behaviour including chromosome association and chiasma frequency young sporophylls were collected between $8.00 \mathrm{am}$ and $5.00 \mathrm{pm}$ directly from the original habitat (north western part of Bangladesh) or from the plants grown in pots or field. The frequency of diakinesis was found abundant between $9.00 \mathrm{am}$ and $3.00 \mathrm{pm}$. It was observed that first half of the day time was best for collection regarding the maximum number of dividing cells. However, grossly there was no hard and fast rule for meiotic timing like mitosis. The young sporophylls were fixed in 1:3 aceto-alcohol immediately after collection. For Adiantum 
$36 \mathrm{~h}$ fixation time was enough whereas $48 \mathrm{~h}$ fixation time rendered good results for Pteris, Ampelopteris and Christella. After 36-48 h of fixation they were transferred to $80 \%$ alcohol and kept in a refrigerator till use.

Suitable sori were placed on clean slide and a drop of $1 \%$ aceto-carmine was added. The sporangia were then ruptured with a flat-ended needle and the indusia and sporangial wall were removed from the slide. Thereafter, the spore mother cells (SMC) were covered with a cover glass, warmed gently over an alcohol flame and a slight pressure was exerted by fingertip to spread out the SMCs as well as the chromosomes. Extra heating was applied with 45\% acetic acid when needed to make the cytoplasm clear. Temporary slides were observed under compound microscope and photomicrographs were taken from the desired preparations. Cytological screening was carried out at all stages of meiosis. A total of thirty stages of diakinesis or metaphase I of each species were studied to analyze the chromosome association. Data on chromosome association and chiasma frequency were recorded form the desired preparations. Chromosome configurations at diakinesis and metaphase I were used to determine the pairing and number of univalent, bivalent or multivalents. The ring or rod bivalents with position or number of chiasmata were also recorded. Other notable observations during meiosis were also recorded.

\section{Results and Discussion}

Chromosome association and chiasma frequency along with the pairing habits of the chromosomes were observed at diakinesis of prophase-I or metaphase-I. Photomicrographs showing diakinesis in SMCs of ten fern species are given in Figs. 1(a-k). The data on chromosome association and chiasma frequency were tabulated and these are given in Table 2.

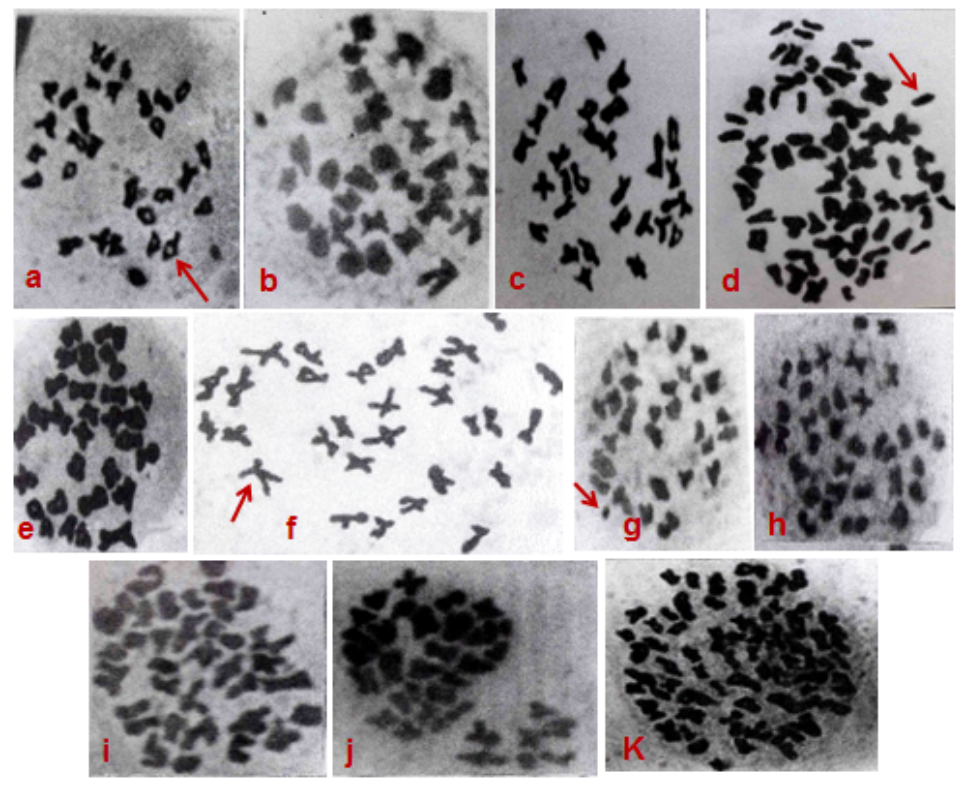

Figs. 1(a-k): Photomicrographs showing diakinesis in SMCs of Adiantum, Pteris and thelypteroid species. a) A. capillus-veneris, b) A. caudatum, c) A. lunulatum (2x), d) A. lunulatum (3x), e) $P$. biaurita, f) $P$ griffithii, g) $P$. vittata, h) C. arida, i) A. prolifera, j) C. cylindrothrix, k) C. dentata. Arrow headed univalemt (1d, $1 \mathrm{~g})$, rod bivalnt (1 f), ring bivalent (1a). 
Table 2. Chromosome number and association determined at diakinesis/ metaphase-1 of ten fern species

\begin{tabular}{|c|c|c|c|c|c|c|c|c|c|}
\hline \multirow{2}{*}{ Species } & \multirow{2}{*}{ 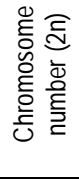 } & \multirow{2}{*}{$\begin{array}{l}\text { Univalent } \\
\overline{\mathrm{X}}_{ \pm \mathrm{SE}}\end{array}$} & \multicolumn{2}{|c|}{ Bivalent } & \multirow{2}{*}{$\begin{array}{c}\text { X-ma per } \\
\text { SMC } \\
\overline{\mathbf{X}} \pm S E\end{array}$} & \multirow{2}{*}{$\begin{array}{c}\text { X-ma per } \\
\text { bivalent } \\
\overline{\mathbf{X}} \pm \text { SE }\end{array}$} & \multirow{2}{*}{ 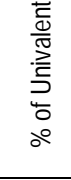 } & \multirow{2}{*}{ 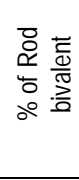 } & \multirow{2}{*}{ 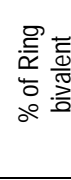 } \\
\hline & & & $\begin{array}{l}\text { Rod } \\
\overline{\mathbf{X}}_{ \pm S E}\end{array}$ & $\begin{array}{l}\text { Ring } \\
\bar{X} \pm S E\end{array}$ & & & & & \\
\hline A. capillus-veneris & 60 & - & $5.50 \pm 0.27$ & $24.50 \pm 0.27$ & $55.30 \pm 0.37$ & $1.84 \pm 0.01$ & - & 15.98 & 84.02 \\
\hline A. caudatum & 60 & $0.80 \pm 0.33$ & $6.50 \pm 0.34$ & $23.10 \pm 0.35$ & $53.90 \pm 0.50$ & $1.79 \pm 0.02$ & 2.63 & 21.38 & 75.98 \\
\hline A. lunulatum & 60 & - & $5.90 \pm 0.23$ & $24.10 \pm 0.23$ & $54.70 \pm 0.30$ & $1.82 \pm 0.01$ & - & 19.66 & 80.34 \\
\hline P. biaurita & 58 & $0.80 \pm 0.44$ & $8.90 \pm 0.31$ & $19.70 \pm 0.26$ & $49.10 \pm 0.43$ & $1.71 \pm 0.01$ & 2.72 & 30.28 & 67.00 \\
\hline P. griffithii & 58 & $0.40 \pm 0.43$ & $15.00 \pm 0.61$ & $13.80 \pm 0.46$ & $42.80 \pm 0.48$ & $1.48 \pm 0.01$ & 1.37 & 51.37 & 47.26 \\
\hline P. vittata & 58 & - & $2.40 \pm 0.31$ & $26.60 \pm 0.30$ & $57.8 \pm 0.70$ & $1.99 \pm 0.02$ & - & 8.27 & 91.73 \\
\hline A. prolifera & 72 & - & $5.10 \pm 0.38$ & $30.90 \pm 0.38$ & $67.60 \pm 0.50$ & $1.88 \pm 0.01$ & - & 14.16 & 85.84 \\
\hline C. arida & 72 & - & $7.60 \pm 0.45$ & $28.40 \pm 0.45$ & $65.60 \pm 0.50$ & $1.82 \pm 0.01$ & - & 21.11 & 78.89 \\
\hline C. cylindrothrix & 72 & - & $5.50 \pm 0.34$ & $30.50 \pm 0.34$ & $67.40 \pm 0.91$ & $1.87 \pm 0.03$ & - & 15.28 & 84.72 \\
\hline C. dentata & 144 & & $22.40 \pm 0.42$ & $49.60 \pm 0.42$ & $121.80 \pm 0.93$ & $1.69 \pm 0.02$ & - & 31.11 & 68.89 \\
\hline
\end{tabular}

SMC = spore mother cells, $\mathrm{SE}=$ standard error.

In general, the nucleus of SMC was eccentric in Adiantum and Pteris species whereas it was central in thelypterids. In A. caudatum central nucleus and in $C$. dentata few eccentric nuclei were also observed. Adiantum capillus-veneris, a diploid sexual $(n=30)$ exhibits extremely uniform cytological status throughout the Indian regions (Roy and Sinha 1956, Mehera and Verma 1960, Manickam 1984, Manton 1950) though exceptions are there. Munshi (1994) observed $n=30$ and $n=31$ having 64 spores in $A$. capillus-veneris. Singh and Roy (1988) observed two types of $A$. capillus-veneris, one tetraploid $n=60$ and the other apogamous triploid with $n=2 n=90$. The cytotypes differed morphologically vary slightly. In the present investigation thirty distinct bivalents were enumerated (Fig. 1a\&c).

In A. caudatum, different cytotypes are available. Manton et al. (1967) and Ghatak (1962) reported wild diploid and sexual forms of $A$. caudatum from West Bengal, Assam, Bihar state, etc. In the present study sixteen spore mother cells resulting 64 spores were observed in sporangium which appeared to be diploid sexual. Triploid apogamous, $n=2 n=90$ is the commonest form of $A$. lunulatum (Mehera and Verma 1960, 1963, Verma and Loyal 1960, Singh and Roy 1969, Verma 1961, Ghatak 1963a, Roy and Sinha 1961). In addition to this diploid sexual, $n=30$ (Bir and Verma 1989, Mahable and Kamble 1981), diploid apogamous, $n=2 n=60$ (Bir and Verma 1989); and tetraploid sexual, $n=60$ are also available (Bir and Verma 1989, Verma 1961, Abraham et al. 1962).

However, A. lunulatum was found with wide range of morphological variations. Tetraploid sexual and triploid apogamous did not yield any significant morphological differences (Bir and Irudayaraj 2001). In the present 
study triploid apogamous and diploid sexual forms were investigated and its wide morphological variation was followed. However, Mehera (1944), Mehera and Verma (1960 \& 1963) reported four cytotypes of $A$. lunulatum from Darjeeling area, e.g. diploid apogamous rare, triploid apogamous commonest, diploid sexual quite common and tetraploid sexual occasional. Mehera and Khullar (1977) from eastern Himalaya observed 4 types of this species and the smaller form of this area was renamed as $A$. teestae.

Pteris biaurita, $P$. griffithii and $P$. vittata were recorded to be $n=29$ as diploid in the present study. However, different cytotypes were discovered by various cytologists. Pteris biaurita was reported as $n=29,2 n=58$ diploid sexual, $n=2 n=58$, diploid apogamous (Abraham et al. 1962), $n=87$, triploid apogamous (Verma and Khullar 1965), $2 n=87$, triploid, irregular meiosis (Ghatak 1963b) whereas $P$. vittata was found with $n=$ 29, diploid (Ammal and Bhavanandan 1991), $n=58$, tetraploid (Roy and Pandey 1962, Kuriachan 1973, Kuriachan and Ninan 1976, Verma 1973, Srivastava and Pandey 1985), 2n = 174 hexaploid (Abraham et al. 1962).

In thelypterids, all the species were observed to be diploid sexual except $C$. dentata when it was tetraploid (Fig. 1 h, i, j \& k). C. arida was reported earlier as $2 n=72$, diploid sexual (Loyal 1961b \&1991), C. cylindrothrix as $2 n=72$, diploid sexual (Loyal 1961b \&1991, Vasudeva and Bir 1982) and A. prolifera as diploid sexual, $n=36$ (Loyal 1961b \&1991, Manton and Sledge 1954, Singh and Roy 1988, Mehera and Loyal 1956, Abraham et al. 1962, Vasudeva and Bir 1982). Mahable and Kamble (1981) reported different basic number as $n=41$ whereas $C$. dentata was reported as $n=36,4 x$ tetraploid (Loyal 1961a,b \& 1991, Paingrahi 1992, Manickam 1984). Manickam (1984) also reported diploid dentata with $n=36$ referring Loyal (1961a) and Ghatak (1961). However, this may be erroneously cited because in his later publication Loyal (1991) mentioned it as tetraploid sexual or amphidiploid. Meiosis was almost regular in the species observed in the present study. In A. caudatum, bridges were observed in a few of anaphase-1 and presence of univalent in triploid apomictic $A$. lunulatum was common feature. An intensive cytological sampling in various populations of $A$. caudatum and $A$. lunulatum was, however, shown that the pairing behaviour was not very much consistent in the SMCs of 16-celled sporangia. Sometimes there may be all pairs or pairs and singles, or multivalents, pairs and singles, and sometimes all univalents (Sinha 1987).

In $P$. biaurita lagging chromosomes and univalents were observed in some cases. Among the species of Adiantum, highest ring bivalent was observed in A.capillus-veneris followed by $A$. lunulatum and $A$. caudatum. Highest number of univalent was found in $A$. lunulatum triploid apogamous form. However, during the study of meiosis, in A. caudatum (Fig. 1b), both dyads and triads were observed. Irregular distribution of chromatin material in $P$. biaurita (Fig. 1e) was observed. In one case of $C$. dentata, triad was observed. In the present investigation the haploid number of Pteris $(n=29)$ and Adiantum $(n=30)$ was in conformity with the earlier reports.

\section{Conclusion}

The present findings are primarily inconformity with many of the researcher's observation as because the conclusive comment can be drawn after working with most of the ferns available in Bangladesh. Due to 
differences of chromosome number many authors suggested in separating Adiantum from Copeland Pteridaceae.

\section{References}

Abraham A (1958). Cytology and taxonomy. Mem. Ind. Bot. Soc., 1: 24-29.

Abraham A, Ninan CA and PN Mathew (1962). Studies on the cytology and phylogeny of the Pteridophytes VII. Observations no one hundred species of South Indian ferns. Journal of Indian Botanical Society, 41: 339-421.

Ammal L and Bhavanandan KV (1991). Cytological studies on some members of Pteridaceae (Sensu Copeland) from South India. Indian Fern Journal, 8: 87-92.

Azad AK, Zaman S, Mazid MA and Kabir G (2012). Karyotype analysis of two epiphytic ferns from Bangladesh. J. Life and Earth Sci., 7: 99-103.

Bir SS (1970). Cytology in relation to fern taxonomy. Symposium on "Modern trends in taxonomy". Indian Bot. Soc. Golden Jubilee Session. Abst. pp. 7-9.

Bir SS (1973). Cytogenetics of pteridophytes. In: Jaiswal et al. (Eds), Genetical Research in India, ICAF, New Delhi, 1: 28-119.

Bir SS and Trikha CK (1979). The polyploid ferns: their classification, characteristics and evolution. New Botanist, 6: 25-32.

Bir SS and V Irudayaraj (2001). Cytology of some ferns from the Nilgiris, South India-IV. Fern Gazette, 16(4): 177-190.

Bir SS and VermaSC (1989). Chromosome atlas of Indian Pteridophytes. Dept. of Environment and Forests, Govt. of India, New Delhi, I-XVIII. pp. 1-1239.

Copeland EB (1947). Genera Filicum. Chronica Botanica Co., Waltham Mass, USA. vol. 5, pp. 1-247.

Ghatak J (1961). Some meiotic counts on the ferns from the Khasia-Jaintia Hills.Proc. 48 ${ }^{\text {th }}$ Indian Sci. Congr., Session. Roorke. Part III, Abst. pp.270.

Ghatak J (1962). Observations of the cytology and taxonomy of some ferns from India. Nucleus, 5: 95-114.

Ghatak J (1963a). Apogamy in Adiantum philippense L. and its cytology. Bull. Bot. Soc. Bengal, 13: 63-65.

Ghatak J (1963b). Observations on the cytology and taxonomy of some ferns from India. Proc. Indian Sci. Congr. Assoc., 50th Session, Delhi, Part III, pp. 371-372.

Kabir $G$ and Mannan MA (2001). A report on the chromosome number of six fern species of Bangladesh, Ann. B. Bot. Conf., Bangladesh Botanical Society, Abst. pp. 7.

Kuriachan PI (1973). Studies on cytology and gametophytes of the south Indian pteridophytes. PhD thesis. University of Kerala, India.

Kuriachan PI and NinanCA (1976). Cytological evolution of the fern family Pteridaceae (Sensu Copeland). Aspects of Plant Science. Today and tomorrow's Print and Pub. New Delhi, 1: 126-154.

Loyal DS (1961a). Cytological studies in Himalayan Thelypteridaceae II. Cytology of Cyclosorus Link., Abacopteris and Ampelopteris Kunze. Proc. Ind. Sci. Cong. Assoc. 48th session, Roorke, Part III, Abst. pp. 266-267.

Loyal DS (1961b). Chromosome numbers in Himalayan Ferns. In: Mehera PN, Res. Bull. (NS), Punjab Univ. Sci., 12: $139-164$. 
Loyal DS (1963). Some evolutionary trends in family Thelypteridaceae with particular reference to Hmalayan species. Mem. Indian Bot. Soc., Phylogeny and Evolution in Pteridophytes, 4: 22-29.

Loyal DS (1991). Cytomorphological studies in the Eastern Himalayan Thelypteidaceae. Perspectives in Pteridology: Present and Future. Aspects of Plant Sci., 13: 171-248.

Mahable TS and Kamble SY (1981). Cytology of ferns and other pteridophytes of western India. Proc. Ind. Nat. Sci. Acad., 47(2): 260-278.

Manickam VS (1984). Cytology of thirty species of ferns from Plani Hills (South India), Cytologia, 49: 49-59.

Manton I (1950). Problems of cytology and evolution in Pteridophyta. The syndics of the Cambridge University press. London.

Manton I and Sledge WA (1954). Observations on the cytology and taxonomy of the Pteridophytic flora of Ceylon. Phil. Trans. Roy. Soc. London, 238: 127-185.

Manton I, Ghatak J and Sinha BMB(1967). Cytotaxonomic studies in the Adiantum caudatum comples of Africa and Asia, I. Parentage of $A$. indicum Ghatak. J. Linn. Soc. (Bot), 60: 223-235.

Mehera PN (1944). Cytological investigation of apogamy in Adiantum lunulatum. Proc. Nat. Acad. Sci. India Series B, 14: 189-204.

Mehera PN and Khullar SP(1977). Biosystematics of Adiantum lunulatum Brum. complex in India with special reference to W. Himalayan taxa. Cytologia, 42: 501-51.

Mehera PN and Loyal DS (1956). Colchicine effect on the prothalli of Goniopteris multilineata (Wall.) Bedd. And G. prolifera Roxb. with emphasis on abnormal spermatogenesis in polyploid prothalli. Ann. Bot., 20: 545-552.

Mehera PN and Verma SC (1960). Cytotaxonomic observations on some West Himalayan Pteridaceae. Caryologia, 13 : 619-650.

Mehera PN and Verma SC (1963). Polymorphocity and cytogenetics of Adiantum lunulatum complex. J. Indian Bot. Soc., 42: 110-121.

Munshi AH (1994). Cytotaxonomic studies on genus Adiantumin Kashmir Himalaya. Indian Fern Journal, 11: 68-72.

Panigrahi G (1962). Cytology and its contribution to fern systematics. Proc. Summer School in Bot., Darjeeling, CSIR, New Delhi, pp. 261-275.

Panigrahi G (1992). Taxonomic, cytological and genetical observations on certain species of Cyclosorusparasiticus (L.) farwell complex (Thelypteridaceae ching Ex Pichi sermoli). aspects of plant sciences. Prespectives of Pteridology; present and future.

Roy RP and Pandey SN (1962). Cytological studies of the fern flora of Parasnath Hills. Proc., Ind. Sci. Congr., 49: 333-334.

Roy RP and Sinha BM (1956). Meiotic studies in the genus Adiantum. Proc. Ind. Sci. Cong. Assoc., 45 $5^{\text {th }}$ Session, Part III, Abst. pp. 284.

Roy RP and Sinha BMB (1961). Meiotic studies in the genus Adiantum. Caryologia, 14: 413-428.

Singh JB and Roy SK (1969). Cytotaxonomy of Adiantum. Nucleus, 12: 173-177.

Singh VP and Roy SK(1988). Cytology of forty four species from Sikkim Himalaya, Ind. Fern. J, 5: 162-169. 
Sinha BMB (1987). Some significant cytogenetic observations in ferns and fern allies. Aspects of plant sciences. Bir SS (Ed.). Todays and Tomorrow's printers and publishers. 9: 85-101.

Srivastava RB and Pandey SN (1985). Cytotaxonomical Investigation in the genus Pteris from Indo-Nepal border region. Proc. of Ind. Sci. Congr.Assoc.,17 th Session, Thirupathi 1982. pp. 37.

Vasudeva SM and Bir SS (1982). Chromosome number and evolutionary status of ferns and fern allies of Pachmari Hills, (Central India). Aspects of plant sciences. Today and tomorrow's Printers and Publishers. New Delhi, 6: 119-181.

Verma AK (1973). Effects of X-radiation on morphology and chromosome pairing in Pteris longifolia I. Proc. Ind. Sci. Congr. Assoc., 60: 325.

Verma SC (1961). Chromosome Neubersin Himalayan ferns, In: Mehera PN (ed), Res. Bull., Punjab Univ. Sci., 12: 139-164.

Verma SC and Khullar SP (1965). Cytology of some W. Himalayan Adiantaceae (Sensu Alston) with cytotaxonomy comments. Caryologia, 18: 85-106.

Verma SC and Loyal DS (1960). Chromosome counts in some ferns from Nainital. Curr. Sci., 29: 69-70.

Walker TG (1973). Additional cytotaxonomic notes on the Pteridophytes of Jamaica. Trans. R. Soc. Edinb., 69: 109-135.

(Manuscript received on 15 December 2020; revised on 21 February 2021) 